\title{
Infanticide at Port Phillip: Protector William Thomas and the witnessing of things unseen
}

\author{
Marguerita Stephens
}

[My informant Bairuk] could not remember any case of deserting infants or of killing them. But he remembered one case of a man near Berwick who eat a child. This man was a Bunjil. (A. W. Howitt 1881)

But I see plainly, he says, that I cannot see. ... If there is not ground for a candid thinker to make up his mind, yea or nay - why not suspend the judgment? (Ralph Waldo Emerson, Representative Men: Montaigne)

Turn the pages of any omnibus ethnology, anthropology or history of Aboriginal Australia published from the late eighteenth century through to the early twentyfirst century and there is a good chance that you will find an entry on infanticide. ${ }^{2}$ Along with cannibalism, infanticide has stood as a leitmotif for the perceived savagery and, at times, the sub-humanity, of the Australians just as it has done for other inhabitants of the non-metropolitan world. And yet these paired tropes of savagery - the one circulating predominantly within a terrain of contested masculinity, the other predominantly of contested femininity - always circulated in fluid discourse wherein the very uncertainty that surrounded claims about their performance invited surveillance and the interrogative operations of the colonial state. ${ }^{3}$

I have argued elsewhere that in the southern colonies of Australia, and specifically in the Port Phillip District of New South Wales, Europeans and Aborigines shared a disdain for, and a fear of, 'strangers' - black or white and hence, that European enquiries about infanticide found ready confirmation amongst unneighbourly tribes; that such discourses flourished despite a dearth of evidence, and came to form part of the ground upon which colonial strategies of Aboriginal child 'rescue' and institutionalisation were constructed from the

1 Howitt Papers, State Library of Victoria (SLV) MS 9356, Box 1053/2 (b): 22.

2 Nineteenth-and early-twentieth-century authors who note infanticide are discussed in Cowlishaw 1978: 262-282. See also Broome 2005: 32; Federal Court of Australia 2000 ('Lorna Cubillo and Peter Gunner $v$ Commonwealth of Australia') (Action 14 and 21 of 1996) Judgment Summary, O'Loughlin J. 11 August 2000: paras 58, 821; Fels 2010: 25-31; Hamilton 1989: 236-258; Hamilton 1981: 123; Howson 1999: 11-12; Kociumbas 2001: 138-160; Russell 2007: 18-46; Thomas 2014.

3 The article is concerned with infanticide as a defining and instrumental trope. That occasional infanticides have occurred in Aboriginal communities, as in most other communities, is likely. What is at issue here is the extent to which it was either a common and customary practice, or a practice instituted in response to colonial occupation. 
1860s onwards. ${ }^{4}$ As with cannibalism, the evidence for infanticide is most often spectral, its transmission provoked, argues Geoffrey Sanborn, by a desire to unearth and to assert knowledge about colonised peoples to a variety of ends from the exterminatory to the humanitarian. As with cannibalism, discourses on infanticide most often inhabit the terrain of the unseen, in which the 'witness' (good or bad) 'sees only a fragment and then imagines the rest in the act of appropriation'.$^{5}$ Like the cannibal of the (missed) colonial encounter, infanticides remain uncaptured. ${ }^{6}$

But while the actual practice of infanticide remains illusive, the instrumental value of infanticide discourse is more easily captured. Satadru Sen argues, in relation to India, that beliefs about infanticide enabled British administrators to set up 'an elaborate regime of surveillance and policing' in which whole castes and whole villages became defined as 'infanticidal'. Infanticide, he argues,

belonged to the trope of colonial discovery, i.e., the crime had become a trophy of empire, and a major marker of racial/cultural difference ... part of the "ground" ... on which the colonizing mission could be justified, extended, and contested. ${ }^{7}$

'This was not', Sen argues, 'so much a conversation about children's lives, as it was about the legitimacy of the interventionist state' ${ }^{8}$

The question of whether infanticide was or was not practised by Kulin people at Port Phillip - either as customary practice or in despairing or resistant response to colonial dispossession - remains the subject of debate and the insubstantiality of evidence alone does not prove the negative: that infanticide was not performed, that it was not customary. This paper focuses on the shifting accounts of two 'good witnesses' (by bent of proximity alone) - William Buckley and William Thomas - and argues that the 'truth' of the matter is, and must remain, at best, clouded. After escaping from the short-lived convict settlement at Sorrento, on the south-eastern arm of Port Phillip Bay, in 1803, Buckley lived amongst the Wathaurung people of the Bellarine Peninsula until he 'came in' to John Batman's occupation party in July 1835. William Thomas was Assistant Protector under the Port Phillip Protectorate headed by George Augustus Robinson from 1839 to 1849, and then served as Guardian of Aborigines from 1850 until his death late in 1867. Like Buckley, Thomas lived in close proximity to the Kulin tribes who frequented Melbourne and he frequently 'itinerated' with them through central Victoria and the district of 'Western Port'. Arguably, no two European men were better positioned to observe the intimacies of Aboriginal cultural practice in the early colonial period; and many later accounts of infanticide practices drew on

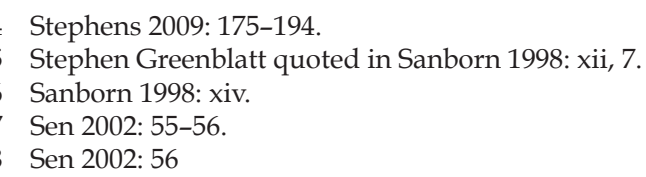


those of Buckley and Thomas. ${ }^{9}$ Thomas himself referenced Buckley's account in his own ruminations over the question of whether the women in 'his tribes' were practising infanticide under his very nose. And yet both of these wellplaced, 'good witnesses' wavered in the evidence they brought to a discourse that materially contributed to marking the Aborigines of Victoria as subjects requiring intense colonial surveillance and intense legislative intervention. Buckley was closely interrogated on the subject by a number of significant chroniclers of life at Port Phillip. Thomas, as befitted a colonial official, kept a daily journal for the whole period of his employment. It details his struggles to make meaning in the interstices between popular belief about particular practice and the evidence of his own experience, and, uniquely, gives us a few precious words from Aboriginal women and men themselves on this subject.

Imperial interest in infanticide came in waves. Raised into legislative focus in relation to India in the Bengal Code of 1795, it was 'rediscovered' there in the early 1820s and came to prominence when the House of Commons reprinted East India Company correspondence and reports on infanticide and suttee in 1824. ${ }^{10}$ In the Australian context, infanticide entered the field of knowledge about natives as early as 1798 when David Collins' description of what could have been better described as a mercy killing of an infant at Botany Bay was taken up by Malthus as an instance of population limitation amongst 'savages'. ${ }^{11}$ Sturt included an exposé of infanticide amongst Aborigines met on his journeys of 1829-31 into the interior of New South Wales (unseen by him but related to him by a white stockman).$^{12}$ New South Wales Presbyterian elder, John Dunmore Lang, in London in 1834, alerted his evangelical colleague, the influential parliamentarian Thomas Fowell Buxton to its practice, and to its purported connection with the decline of the Aboriginal population of New South Wales: their numbers, he told Buxton, were rapidly diminishing 'from the prevalence of infanticide, from intemperance, and from European diseases', and they faced 'utter extinction'. ${ }^{13}$ In 1836 infanticide was identified as a cause of Aboriginal decline by Dandison Coates, secretary of the Church Missionary Society, before the Select Committee on the Aborigines in British Colonies ('The Aborigines Committee') chaired by Buxton. ${ }^{14}$ Thus, by the mid 1830s, two powerful,

9 Buckley's evidence was circulated in Wedge 1836: 419-424; Howitt and Fison 1880: 190, 190n; Howitt 1996 [1904]: 750; Bonwick 1883: 235-236. Thomas' statements on the subject were circulated in Westgarth 1846 and 1848.

10 Sen 2002: 55; Caldwell and Caldwell 2002: 205-227. Lester and Dussart note that in the same year, the British Government also established a 'Protectorate of Slaves' in Trinidad. Lester and Dussart 2008: 208

11 Collins 1798, I: 65, 597-598, 606-608, 608n; Malthus 1798: 23-24; Clendinnen 2003: 225-227, 260-261.

12 Sturt 1833, II: 222-223.

13 Lang to Buxton 10 June 1834, in House of Commons 1836, Minutes of Evidence on Aborigines (British Settlements): 682, 684. See also summary of the letter in William Thomas Papers, Mitchell Library (ML) MS 214, Reel 1, frame 24-25.

14 House of Commons 1836, Minutes of Evidence on Aborigines (British Settlements): 486-487, $502,539,684$. 
signifying discourses intersected: that of Aboriginal savagery signified by the killing mother, and that of the Aborigines as a dying race - seemingly bound for extinction in the face of European colonial expansion.

By the mid 1830s, the colonial government of New South Wales was under enormous pressure to unlock the lush grasslands of the Port Phillip District. In June 1835 John Batman and the Port Phillip Association laid claim to around 240,000 hectares $(600,000$ acres) of land, as 'beautiful' and 'as rich ... as I ever saw', with 'grass of the best description', wrote a jubilant Batman. ${ }^{15}$ At the northern end of Port Phillip Bay, Batman located a party of Wurundjeri (or, more likely, was located by that party), and six of the senior men made their mark on a treaty prepared in advance by Batman: he later argued that they fully understood that they were signing over their lands in exchange for an annual tribute of tools, blankets and rations. Whatever the true meaning of the agreement for the Kulin, ${ }^{16}$ it was invalidated in London in January 1836 on the grounds of prior claim to the territory by the British crown. But in their judgment, Justices Burge, Follett and Pemberton invited the Port Phillip Association to avoid being 'ousted' from their new estate by making application to government laying out 'every ... circumstance connected with the acquisition'. ${ }^{17}$

Those circumstances, as publicised by George Mercer, the Association's advocate in Britain, gave finely tuned prominence to the Association's 'philanthropic' and evangelical motives, and to the 'understanding' of agreed terms that Batman had been advised by Sir George Arthur (Lieutenant Governor at Van Diemen's Land) to secure with the Aborigines of Port Phillip. ${ }^{18}$ Mercer was able to report in April 1836 that

15 Batman Journal, May-June 1835, SLV MS 13181: 31, 32.

16 While Batman's claim was surely exaggerated, Robert Kenny has argued (Kenny 2008: 38.5, 38.7) that the claim may not have been without some merit: that the Kulin signatories may have sought to ameliorate what they recognised as the inevitable occupation of their Country (having ample foreknowledge from northern neighbours) and have entered with deliberation into an agreement with Batman, enacted through a coincidence of mutually misconstrued rituals, with the intention of negotiating and limiting the inroads of the newcomers and obtaining coveted technologies. Indeed, William Thomas' journal records a statement made late in 1839 by Billibellary, one of the signatories to Batman's 'treaty', that suggest that the failure of later-comers to honour Batman's agreement was a source of discontent amongst the Kulin clans. '31 December 1839. I press'd them hard to leave but to no effect, they said that Borak Gago, plenty long time ago Black fellow Burrow long time nge. Mr Batman \&c \&c gave Plenty Yellow [Nilra?] Curran \&c \&c like now Plenty for Goldbrn \& Port Phillip Black fellow Melbourn.' See also Thomas' Quarterly Report of 1 January 1840 in which he reported that Billibellary had complained about the lack of rations and the pressure on the clans to leave Melbourne, and asked 'why you want Blackfellow away, plenty long time ago Mereguk Batman come here Blackfellow stop long long time all Black fellow, plenty bread plenty sugar, Blanket \&c': Thomas Quarterly Report, 1 January 1840, Public Record Office Victoria (PROV) VPRS 11, item 292. Similar claims are made in relation to the New Zealand Treaty of Waitangi in Morris 2014 (forthcoming): 60.

17 Opinion of Justice Burge, 16 January 1936, Redmond Barry Papers, 'Table of Cases \&c', SLV MS 8380 , Box 597/2.

18 'Sir George Arthur', in Australian Dictionary of Biography (AGL Shaw, 1966). Saxe Banister, Attorney-General of NSW 1823-26, also advocated a treaty as being 'indispensable towards ensuring justice to the Aborigines' of New South Wales: Bannister letter to Buxton, August 1835, in House of Commons, 1836, Minutes of Evidence on Aborigines (British Settlements), p.177. 
Buxton, unsolicited ... by me, has, on perusing the documents tendered his advocacy in the House, in support of the system we have adopted in reference to the natives, declaring that he will never acknowledge a right to deprive them of the lands, without compensation, protection, food, \& ${ }^{19}$

Arthur (who had long-standing connections with Buxton and with Lord Glenelg and James Stephen at the Colonial Office) ${ }_{,}^{20}$ Batman, Mercer and the British judges had rightly wagered that Buxton's concern for the territorial rights of the colonised would be tempered by the offer of compensation as laid out in the treaty, but more so by the Association's plan to send missionaries to proselytise amongst the Aborigines at Port Phillip. Despite the formal invalidation of the treaty, Batman's venture at Port Phillip was assured of continuation when, in June 1836, Buxton and the secretaries of Britain's most prominent mission societies jointly laid out, before the Aborigines Committee, a calculus of imperial humanitarianism in which the transmission of Christianity was measured as both 'fair and adequate compensation' for the appropriation of Aboriginal lands, and, happily, 'as the only compensation we can afford'.$^{21}$

Amongst the documents circulating in London in 1836 in support of Batman's 'treaty' was testimony taken from William Buckley in August the previous year by the Association's surveyor, John Helder Wedge, confirming the Aborigines of Port Phillip as infanticides, a claim perfectly calculated to commend them to British humanitarians as a people in dire need of Christian salvation. Under questioning from Wedge, Buckley had readily agreed that infants were unceremoniously killed by their mothers due to

the custom the women have of nursing their children till they are three or four years old; to get rid therefore of the trouble and inconvenience of finding sustenance for two; should a second be born before the eldest is weaned, they destroy the youngest immediately after it is born; [otherwise] ... from mere wantonness; and as it would seem to us ... a total absence of maternal feeling.

'One woman in particular', Buckley allegedly told Wedge, 'had destroyed ten of her children', the last but 'a few days previous to my [Wedge's] arrival at the Port'.22

19 Mercer to Robertson, 23 April 1836, in Mercer Papers, SLV MS 8519, Box 991/4 (b).

20 Lester and Dussart 2008: 210.

21 The joint testimony of the mission society heads on 6 and 8 June 1836 progresses from their condemnation of the colonial project overall due to its ill effects on Aborigines, to a conclusion that only through missionary endeavour could the Aborigines of Port Phillip be saved. It was Buxton who assisted them out of the dilemma into which they had argued themselves. House of Commons, 1836, Minutes of Evidence on Aborigines (British Settlements): 481-516, especially, p. 516.

22 Mr Wedge's Narrative of an Excursion Amongst the Natives of Port Phillip', SLV MS 6332, MF 63. 
The likelihood that Buckley could accurately enumerate the sequential killing of infants across decades, and the 'just missed' quality of the testimony as mediated through Wedge, might suggest the operation of motives other than 'good witnessing' here, on the part of both Wedge (arguing for the Port Phillip Association's territorial claim) and Buckley (arguing for a pardon); yet Buckley's testimony fed the humanitarian claims of the association too well to be queried. Buckley was soon pardoned and appointed as interpreter and superintendent over the tribes at Port Phillip.

In concert, these high-level revelations at 'home' and in the colonies, positioned infanticide as a defining aspect of Aboriginal culture. Like the people of the sub-continent, by the mid-1830s the Australians were deemed to be infanticidal, and the children of the Aborigines, in particular, emerged as subjects requiring humanitarian intervention.

By 1836 missionaries were active at Port Phillip. On 20 April 1836, Reverend Joseph Orton of the Wesleyan Mission Society arrived from Van Diemen's Land. Almost immediately, he wrote, 'I met the celebrated Buckley ... I hope to be able to obtain considerable information from him'. Buckley obliged with a by now well-rehearsed narrative.

I gather[ed] several interesting facts regarding the natives [from Buckley]. ... I was shocked to learn, not only that they are cannibals, but that ... [t]hey are frequently in the habit of devouring their own offspring. When they happen to have a second child unable to walk, from the great inconvenience of carrying them in the course of their wanderings, one of them is sacrificed and eaten by the parents. ${ }^{23}$

Over the course of the next few days, Orton also met a party of Aborigines encamped near Batman's hut - and 'I succeeded in making them understand that by and by white men would come to teach their children to read and write, which pleased them much' ${ }^{24}$

In August Orton reported to the Wesleyan Missionary Society in London that he had 'pointedly and repeatedly' interrogated Buckley and had no doubt that they practised infanticide: 'my own observation of the disparity of years between children of the same parents at least collaterally supports the fact'. He also reported the interest of the Aborigines in having their children taught to read and write. ${ }^{25}$

Arriving at Port Phillip in January 1837, under instruction to establish an Anglican mission, George Langhorne also interrogated Buckley on the subject of infanticide, but Langhorne's account indicates some moderation in Buckley's testimony. Rather than the wanton killers of incommodious infants, Buckley now recounted that the people who had given him succour had large families and

23 Orton, Journal, 20 April 1836, SLV PA 94/23.

24 Orton, Journal, 23 April 1836, SLV PA 94/ 23.

25 Orton, Letterbook, August 1836, SLV PA 94/ 23. 
were 'much attached' to their children; that they practised a form of ritualised mortuary cannibalism on the bodies of slain adversaries; and that 'they eat also of the flesh of their own children to whom they have been much attached should they die a natural death' ${ }^{26}$ In this account there was no mention of customary infanticide, and no infants under familial threat. What motivated Buckley to construct his various accounts (and how far his accounts were modified in transmission) can only be guessed at, but there is a clear reining in of his account between 1835 and 1837. But this moderated rendition could hardly compete with the sensational and instrumental first take, which circulated through the mythos of Australian savagery well into the twentieth century.

In its final report of 1837, Buxton's committee called for the establishment of an 'Aboriginal protectorate' at Port Phillip. A rudimentary plan for a protectorate in New South Wales had come from both John Dunmore Lang and from Sir George Arthur. In a letter to Buxton in 1834, Lang had suggested the appointment of a 'suitable person as Protector of the Aborigines' and 'a Board of Protection, to consist of certain officers of the Government, certain ministers of religion ... and certain private gentlemen in the colony, distinguished for their active philanthropy ${ }^{\prime 27}$ Sir George Arthur, in London during 1837, was put in charge of recruiting the personnel for the venture. ${ }^{28}$

Amongst those chosen by Arthur to serve as one of four Assistant Protectors under Chief Protector George Robinson (Arthur's ally in near-genocide at Van Diemen's Land) was William Thomas, a middle-aged London schoolmaster with patronage in Buxton's evangelical circles. Appointed in December 1837, Thomas, his wife Suzannah, and their four children, arrived at Port Phillip on 3 January 1839. Thomas' Port Phillip journal, extending from 1839 to 1867, records the prevalence of settler belief in Aboriginal infanticide, and allows us to trace the changing course of Thomas' own position regarding the purported practice - from initial disbelief, to an (at times wavering) affirmation even in the face of consistent denials and countering testimony from Aboriginal women and men themselves.

Thomas' initial position was that the widespread settler belief in customary, wanton and frequent Aboriginal infanticide was scurrilous and unfounded. In May 1839, and in close daily contact with the Kulin tribes encamped in Melbourne, he noted the care of a mother for her sick child, remarking that such tenderness

puts a lie upon that Sydney Journal who has asserted that the Aborigines of Australia are less than the brutes in the scale of Existence void of natural affection, destroying their own offspring to save them the trouble of rearing them..$^{29}$

26 Langhorne 1837, Reminiscences of James Buckley..., SLV MS 13483.

27 Lang to Buxton, 10 June 1834, in House of Commons (Britain), 1836: 683.

28 Lester and Dussart 2008: 210.

29 Thomas Journal, 19 May 1839, ML MS 214, Reel 1, frame 52. 
Yet in the face of popular opinion, and the anticipation by the Colonial Surgeon, Dr Cousins, of the inevitable extinction of the tribes of Melbourne if the spiralling death rate could not be halted, ${ }^{30}$ Thomas began to reconsider his position.

On Thursday 13 February 1840, he was alerted to the death of a child in the Melbourne encampment by the lamentations of a woman whose child 'had died just before daylight' and was yet 'quite warm'. The child's father had wrapped it in his own blanket and, Thomas wrote: 'I endeavour' $d$ to unwrap it ... but they seemed very unwilling. I hesitated by observing how warm the child's head felt but they assured me Weakun Picky Picky ... \& they seem much concerted at my suspicions', meaning that they assured him the child had died, and made it clear to him that they were aware of his simmering suspicion of infanticide. In this instance Thomas drew back and, perhaps apologetically, wrote in the margin of his journal: 'Ridiculous has been the sayings of some writers that they kill \& eat the first child or burn it'; but his suspicion was now aroused, and he also noted, unkindly, that they 'soon forget their Dead'. ${ }^{31}$ In the light of later expositions on infanticide, Thomas' inclusion of the Kulin word 'weakun', with its clear meaning here of 'dead', or 'is dead', is of significance, and I will return to it later.

Late in September 1842, Thomas noted in his journal the return to the principal Melbourne encampment (by now at the Merri Creek) of the Woiwurrung man Nerrim Kurruck 'without his Child, says he died in the bush at Beal, but I fear been killed'. The male infant, in Thomas' opinion, had likely been 'put out the way $2 \mathrm{~d}[\mathrm{a}] \mathrm{ys}$ back', but Thomas allowed the matter to go by, only renewing his private vow to 'spiritualize these people'. In the following week, he observed the ceremonial exchange of a child, from a family with surviving children to a childless man - the Brandoo ceremony - noting 'the agitated ... feature of the poor Mother' whose child was to depart. ${ }^{32}$ For Thomas, the ceremony highlighted both the attachment of the women to their children and the dearth, now, of young children amongst the clans.

In February 1843, with most of the surviving Woiwurrung now working to bring in the harvest at the Nerre Nerre Warren Aboriginal station some 40 kilometres south-east of Melbourne, Kurboro informed Thomas that his sister's female child, born three days previous, had died. His suspicions again aroused, Thomas asserted his authority to interfere at such grievous times, and 'examin[ed] ... the body ... very carefully in the presence of several White persons'. It was Thomas' wife Suzannah who offered the opinion, supported by all the Europeans present, that the child had died a natural death brought on by convulsions. 'The Body [was] wrapt again in what it died in ... [and was] accompanied to the grave by its Mother, Uncle, Brother, Aunt \& [its father] Nunuptune'. ${ }^{33}$

30 Cousins in Thomas Journal, 6 May 1839. The prospect of 'extinction' was also raised in correspondence: Robinson to Thomas, 16 September 1839, SLV MS 14624, Box B 'Officials Rec'd/ Official Communications 1839', letter no. 150; and in Thomas draft response to Government Circular of September 1841 in Thomas Journal, ML MS 214, Reel 2, frame 351.

31 Thomas Journal, ML MS 214, Reel 2, frame 57-58.

32 Thomas Journal, 23 and 26 September 1842, SLV MS 14624, Series 1.

33 Thomas Journal, 11 February 1843, SLV MS 14624, Series 1. 
In the spring of 1843, with the dearth of young children and infants in the Kulin population now evident to all, Thomas directly interrogated Billibellary, the Woiwurrung ngurungaeta (headman), on the subject of infanticide, and Billibellary, according to Thomas, confirmed the practice. Thomas' first record of Billibellary's 'confession' is in his private journal:

7 October 1843. I have a long Conversation this day with Billibellary, on the Subject of Killing there [sic] Infants when born, he acknowledged it was so, \& named those who had had children since I had been among them 8 in My tribes only, and only his Suzanna alive, he said they done it with a Cord Generally but sometimes by putting a Koogra all round its head, he said that Black Lubra's say now no good Children, Black fellow say No Country now for them, very good Weikite \& no more come up Pickaniny. I pointed out to him the wickedness of the practice that God would ask all those Lubras when they died where those Children were that they killed. Billibellary promised that he would endeavor to make them let their Children live, he said that there were 3 who would soon have pickaninys, Murry, and he would see that [ENDS]. [Margin Note: Billibellarys Confession, On the awful Infanticide that had existed among them, and stated the Cause, \& his promise $]^{34}$

In his quarterly report to Superintendent La Trobe, composed early in December 1843 some seven weeks later, Thomas reiterated Billibellary's 'confession', with minor variation only, adding that Billibellary had asserted it was 'the lubras [who] made away with them', and (in response to Thomas' pressing them to settle down at the Nerre Nerre Warren station, many miles distant from their chosen place on the Yarra at Bulleen) that:

He [Billibellary] said if Yarra Blackfellows had a country on the Yarra that they would stop on it and cultivate the ground. He told me that there were three lubras who would soon have pickannineys and he would see that they did not kill them. ${ }^{35}$

Thus, by late1843, Thomas had come to believe the prevailing view that infanticide was impacting on Aboriginal populations to such an extent that extinction now loomed. But in linking infanticide to loss of country (as had Billibellary), Thomas moved the discourse onto a more sympathetic terrain than it usually occupied amongst settlers, with a readily available remedy consonant with the mission of the Protectorate and Thomas' own: of converting the Kulin and their children into respectable, Christian, farmers and artisans, permanently settled on land reserved for their use. There was, Thomas told Billibellary, 'country enough for Black and White people if they would but stop in one place'. ${ }^{36}$

34 Thomas Journal, ML MS 214, Reel 3, frame 99.

35 Thomas to La Trobe, Quarterly Report 1 December 1843, PROV, VPRS 4467, 1840-1849 Victorian Aboriginal Protector Returns. See also Broome 2005: 32-33.

36 Thomas to La Trobe, Quarterly Report 1 December 1843, PROV, VPRS 4467. 
This multiform record of Billibellary's 'confession', from Thomas' private journal and from his official quarterly report to Superintendent La Trobe, has been reinscribed into modern historiography by Broome (2005) and by Fels (2010) as evidence that women were killing their infants in despairing response to dispossession. Both have adopted Thomas' sympathetic approach to the purported upsurge of infanticides. Broome argues that such acts were 'clear indications of the despair that colonisation had wrought among the Kulin'; Fels sees them as a response to the 'bitter realisation ... that they had lost their country' and that any meaningful future could not be imagined without their country for their future children. It was, Fels argues, 'not merely a matter of dispiritedness, or dejection or depression ... [but] a positive choice about identity' ${ }^{37}$

And yet Thomas' journal contains later entries that undermine a too ready acceptance of the tragic agency of Billibellary's 'confession' (as passed to us by Thomas), even in its sympathetic, humanitarian, or post-colonial rendition.

Following the conversation of 7 October 1843, Thomas determined to stop the 'killings' in alliance with Billibellary. He recalled many years later that on that evening Billibellary harangued the tribes 'upon the subject, and in forceable language, and I was in hopes that he had succeeded'. ${ }^{38}$ But Billibellary was unsuccessful, for some weeks later, on Monday 18 December, Thomas was alerted to another infant death when 'Jack's lubra appears in Encampment without her infant'. 'I accuse her of killing it she denies it says it was bad in the chest \& all over Buberum \& died 14 days back. ${ }^{\prime 39}$

In mid-January 1844 Thomas again suspected infanticide. In his journal he noted that he had not seen the infant 'Queen Victoria' or her mother for some days and that, on enquiring their whereabouts, had been told the child had died. As women came into the encampment on the northern fringe of Melbourne he questioned them on the child's fate. 'Sunday 21 January 1844 ... Question Eliza touch[in]g poor Queen Victoria but she persists that it died. I very much doubt it. O Lord look down upon these people.' ${ }^{40}$

A week later (28 January 1844), Thomas angrily accused Billibellary of not intervening to prevent the death of Queen Victoria. Billibellary reiterated the women's account of the death: he (Billibellary) 'assures me that the Child lately dead was not killed that it was very bad a whole day \& night \& that the mother did not kill it he would take me to where it was burried' ${ }^{41}$ Thus in the first two instances of suspected infanticide immediately pursuant to Billibellary's 'confession', the accusation was denied, and the cause of death clearly attributed to natural (or rather, introduced) causes.

37 Broome 2005: 32; Fels 2010: 26-27. Fels' interpretation relies in part, though not entirely, on a mistranscription of the word 'weikite' as 'we kill', as discussed below.

38 Fels 2010: 27, 26-31. See also Thomas Papers, ML MS 214, Reel 21-22, frames 48-9.

39 Thomas Journal, ML MS 214, Reel 3, frame 147.

40 Thomas Journal, ML MS 214, Reel 3, frame 166.

41 Thomas Journal, ML MS 214, Reel 3, frame 169. 
Thomas was undeterred. He continued to harangue the women through the autumn and winter of 1844 as more infants died. On Sunday 19 May 1844 he used his morning service to

point out the anger and Determination of God to punish he who ever kills their Children, they paid great attention, \& to my surprise about an hour after many came to my Quarters to hear more of White Mans Laws of Murder.

It was, he noted 'a profitable Sabbath' ${ }^{42}$

But not so profitable, for the 'killings', as he saw them, still continued. On 15 June 1844 he found that Tallenmun of the Loddon River tribe,

has left for the Bush, I fear to sacrifice her poor child, my suspicion was heighten [sic] by seeing the husband with fresh daubs of mourn[in]g. I questiond him very closely but he said she was merely gone with some lubras to get bandagecoots [sic] \&c for skins for sale. ${ }^{43}$

Five days later Tallenmun returned to the encampment without her infant. When questioned by Thomas

she appear'd in great distress \& said the child was dead. I was very hasty to her \& said Oh you wicked Mother you have Killed your poor little babe that suck milk from your breast. When You Die Pungil Marmn will ask you where your little baby, her heart seem'd full, poor creatures. ${ }^{44}$

There can be little wonder that women and their husbands resisted Thomas' insistent and intrusive efforts to know where their infants were buried. He had, in times past, interfered with burials, and bodies had been exhumed for examination by prying whites to the horror of grieving parents; and now, too, he sought to have the body examined by the Colonial Surgeon 'for satisfaction' ${ }^{45}$ Little wonder then that Tallenmun

was very anxious to make me believe that the Child died, but would not take me to where she had burried it, I found her in Mourn[in]g, turn[in] $\mathrm{g}$ to her husband I beg' $\mathrm{d}$ that he would shew me where the child lay but he pretends that only the Old Woman knew.

While in other instances, Aboriginal men and women had simply closed off the conversation with this intrusive 'protector', in this instance, the child's father Nerremunun/Morgan, proposed his own counterpoint to Thomas' accusation of infanticide by 'return[in]g the Box of ointment' that Thomas had provided for the treatment of the ailing infant, and proposing instead to Thomas

42 Thomas Journal, ML MS 214, Reel 3, frame 188.

43 Thomas Journal, ML MS 214, Reel 3, frame 194.

44 Thomas Journal, 20 June 1844, ML MS 214, Reel 3, frame 195.

45 Thomas Journal, 21 June 1844, ML MS 214, Reel 3, frame 196. 
that it was that [the ointment] that kill'd it. ... [Nerremunun] 'took out the Box, on looking at it I found that not a morsel of it had been used I took the box stating that if he or his Lubra did not take me to where the child was burried that I should always say that his Lubra \& the Old Woman had killed the child.

Later the same day Thomas returned to the encampment and again 'endeavor[ed] to get out of Nerremunun where the child was burried but in vain, all I could get from him was that it was burried, and not burnt' ${ }^{46}$

On Saturday 22 June 1844, Thomas again went early to the encampment, and later 'Wait[ed] on the Col[onia]l Surgeon \& report[ed] touch[in]g the child \& my fears' and requested that he also join the search for the body. This hunting party appears not to have located the infant's grave, as the death was recorded in Thomas' end of year table of births and deaths as due to 'suspected infanticide', aged 20 days. $^{47}$

In mid-August 1844, the Mount Macedon people visited Melbourne and, observing the ceremonial signs of mourning on the face of a woman, Thomas again recorded his

fear she has killed her suckling infant, Infanticide is in my opinion much on the increase they say 'no country, no good pickaniney' O Lord stretch out thy delivering hand to save these poor creatures. ${ }^{48}$

Some weeks later, in September, Ningollobin joyously reported to Thomas that he had a son, born four days earlier at Bacchus Marsh, at Captain Backhouse's station. The child's mother was Toulomn. ${ }^{49}$ Five weeks later the infant was dead. On 3 November 1844, Thomas recorded a conversation about the death of this child with the senior woman Murrun, which indicates that the women themselves - those so flatly accused of being infanticidal killers - were struggling to formulate explanations for the torrent of infant deaths that now swept over them.

A conversation with Murrun this day is worth recording. She said 'that Tolomes [Toulomn's] pickaninie was dead, that that Lubra not like other Lubras sit down on Sundays but means all the time she was pregnant would walk about big one Sunday that White Mans God very angry \& when the child was born all over sores \& only live one moon Big one Sulky Pungil Marman because she no narlumby Sunday'. I gave suitable remarks to Murrum \& stated that it was useless her resting on Sunday if she did not think of God. ${ }^{50}$

46 Thomas Journal, 20 June 1844, ML MS 214, Reel 3, frame 195.

47 Thomas Journal, table at 31 December 1844, ML MS 214, Reel 1, frame 284.

48 Thomas Journal, 14 August 1844, ML MS 214, Reel 3, frame 217.

49 Thomas Journal, 28 September 1844, ML MS 214, Reel 3, frame 43.

50 Thomas Journal, 3 November 1844, ML MS 214, Reel 3, frame 235. 
In this counter-explanation, as put to Thomas by Murrun, it is not the actions of Aboriginal women but Thomas' powerful 'white man's god ... Pungil Marman' that is proposed as the agent of the infant deaths. Toulomn, posits Murrun, had refused to participate in Thomas' Sunday services, had continued to 'walk about' on the Sabbath, and as punishment, her child had been born with the signs of congenital syphilis and had died before it was a month old. The god that brought the Europeans, and with them white flour, tobacco, sugar, hunger and sickness, has perhaps also the power to punish those who did not observe the Sabbath in the right manner. It is a powerful argument in the face of such enormous change; but it also points to the struggle of women themselves to make sense of the malign forces that had beset them. That they sought for an explanation in the new suggests that infanticide was not the cause of their infants' deaths, but also that they apprehended that deaths mediated by Thomas' malign and retributive god might perhaps be controlled with Thomas' aid. Indeed, Murrun's explanation sits in a field of explanation not at all dissimilar to Thomas' own worldview: one in which numinous forces impressed themselves directly on human lives, and in which right action - however perceived - might mollify godly wrath. Seen in this light, the connection drawn by the women (and reiterated to Thomas by Billibellary) between the loss of Country and the loss of their children need not turn on active human intervention. Instead, it is a natural articulation of effect and cause in a world turned upside down. As Billibellary had said, 'now no good Children, Black fellow say No Country now for them, very good Weikite [dead] \& no more come up Pickaniny'.

In his official return of 30 November 1844 Thomas reported: 'Infanticide I am persuaded is now awfully on the increase, tho it cannot be detected. Their argument has some reason no good Pickaninys now no country' ${ }^{51}$ From his own records he tallied 76 deaths (all ages) and only 12 births across the six years that he had acted as protector to the Kulin, and as far as he knew, only one infant had survived.$^{52}$ Extinction surely loomed but the cause of the infant deaths was still uncaptured.

In September 1845, Thomas began preparing notes towards a proposed book on the 'customs and manners' of the Aborigines. In those private notes he rehearsed the by-now orthodox infanticide brief: that women showed little compunction in disposing of female infants in particular, and that it was done by strangulation or smothering. But he added, with a modest qualification that suggests some continued, nagging uncertainty, that 'if the child is not made away with before the next new moon, it is generally allowed to live, altho' I have known instances (I have had every reason to expect) of their being destroyed after this date (vide Queen Victoria)' ${ }^{53}$ Ironically, it is Thomas' stealthy qualifiers that position him as a good witness in this search for truth, for after two years of close interrogation of Aboriginal women he had not found 'ocular' proof. ${ }^{54}$ Perhaps he also took heed

51 Thomas Quarterly Report, November 1844, ML MS 214, Reel 1, frames 285-286, italics added.

52 Thomas Papers, ML MS 214, Reel 1, frames 284-6, 'Outline of sundry reports ...'.

53 Thomas Papers, ML MS 214, Reel 3, frame 43, italics added.

54 Sanborn 1998: 6. 
of the conversation with Murrun and the other women and men who challenged his accusations, for by the time his notes turned into a pair of articles on the 'manners and customs' of the Kulin in the Port Phillip Patriot in January 1845 (15th and 24th) his comments on infanticide were even more circumspect: he wrote only that infanticide was limited to the despatch of infants whose mothers died while they were as yet unweaned. ${ }^{55}$

And yet, this circumspection was short-lived. In response to a circular issued in September 1845 by a Select Committee of the NSW Legislative Council bent on winding up the Protectorate, Thomas wrote unequivocally:

[Infanticide] is [known among them], and I fear a growing evil; they were ever accustomed to destroy the fruit of the womb till a male was born, but now, I have reason to believe that male and female are alike destroyed; one chief has acknowledged to me that he has no power to stop it; the blacks say 'no country, no good have it pickanineys'.$^{56}$

With the Protectorate under concerted attack from settlers who argued, in petitions to the New South Wales legislature, that the rights of Aborigines were held above their own rights and that its cost was exorbitant given the parlous state of the local economy, and with the humanitarian mission to civilise and Christianise the Aborigines now widely derided by settlers, ${ }^{57}$ Thomas was under some pressure to present himself as a man of authority and objectivity about Aboriginal matters. He leaned, therefore, away from his own inconclusive witnessing towards the orthodoxy of the infanticidal savage. Perhaps, too, he may have perceived some benefit in arguing that they would soon be extinct through their own devices rather than through any failure of action on his part. But Thomas was not a man to plot and prevaricate, and the emotional centre of gravity in this response is in the unhappy inevitability of his failure and their disappearance. Thomas' authoritative confirmation reappeared in William Westgarth's Report on the Condition, Capabilities and Prospects of the Australian Aborigines published in Melbourne in 1846, and in his Australia Felix published in London and Edinburgh two years later. Infanticide was prevalent and 'established beyond any reasonable doubt' and was 'systematically pursued' by the Aborigines of Victoria, wrote Westgarth, one of Port Phillip's leading citizens. ${ }^{58}$ Notably, Westgarth passed over replies to the committee from correspondents who declined to confirm the practice.

55 Thomas, 'Manners and customs of the Aborigines', Port Phillip Patriot, 24 January 1845.

56 New South Wales, Select Committee on the Condition of the Aborigines (NSW, Legislative Council, Votes and Proceedings, October 1845, replies to circular: 56). See also Victoria, Select Committee on the Aborigines (Victoria, Legislative Council, Votes E Proceedings, 1859: 10, 12) in which William Hull attributes virtually the same statement to the Boonwurrung headman Derrimut in the mid 1850s. (Compare Fels 2010: 25-26).

57 Lester and Dussart 2008: 210-213. For the cost of the Protectorate and the drastic cut in its budget in 1843, see Auditor General's report appended to New South Wales, Select Committee, October 1845. Thomas' reply to the circular: 55-58.

58 Westgarth 1846: 14; Westgarth 1848: 59. 
Thomas recorded two further episodes of suspected infanticide. On 8 September 1846, at the Merri Creek encampment, he noted that Kitty's infant was gone,

she says been dead $3 \mathrm{~d}[\mathrm{a}] \mathrm{ys}$, have my doubts of it, she nor her husband will not tell me where they have buried it, I feel very dissatisfied but the poor woman is so ill that I dare not too much frighten her, get home by 5 o'clock, much regretting the little infant, who I fear is put out of the way.

Two months later, Billibellary's daughter arrived at the Merri Creek encampment, 'much affected' and daubed in mourning clay following the death of her father, and without her infant. 'Poor innocents', wrote Thomas, 'I fear all are put out of the way. ${ }^{59}$

Beyond 1846, Thomas' journal contains no further reference to suspected infanticides, but publicly he continued to urge it as a partial explanation of Aboriginal population decline, always making the connection between the alleged despatch of infants and the loss of country. In reply to the circular issued in 1849 by yet another select committee of the NSW Legislative Council intent on winding up the Port Phillip Protectorate, Thomas positioned infanticide as one, but one only, of the causes of Aboriginal population decline. He attributed their decline,

First to their connexion with the white population bringing the venereal disease; ... when I came among them, old and young, even children at the breast were affected with it; I have known hapless infants brought into the world literally rotten with this disease. Second, a redundancy of males, and debauchery among themselves. Third, their indifference to prolong their race, on the grounds as they state, 'of having no country they can call their own', hence should there be a birth the infant is artfully put out of the way. ${ }^{60}$

But in his private journal, where his thoughts went unwitnessed, Thomas continued to record his uncertainty on the subject. His responses to enquiries from the Victorian Select Committee on Aborigines of 1858-59 are a case in point. Testifying before the committee on 1 November 1858, Thomas stated, 'We have only one child left, ... I do not say they have not had children, but they have been made away with. ${ }^{61}$ In his written response to the circular of that committee, as printed, he replied, with equal clarity: 'it does [occur], and that to an almost universal extent' ${ }^{62}$ But Thomas' private papers contain a longer, more detailed draft of his response to the circulated queries of 1858, which tellingly records, yet again, the lack of objective proof behind his public declarations. 'Infanticide', he wrote, 'has existed among them [due] to the releasing them of the trouble in rearing their offspring', he again recounted Billibellary's admission 'that

59 Thomas Journal, ML MS 214, Reel 3, frames 376, 398.

60 New South Wales, Select Committee on the Aborigines and Protectorate (NSW, Legislative Council, Votes and Proceedings, September 1849: 55).

61 Victoria, Select Committee 1859, minutes of evidence: 3, Q 47-48.

62 Victoria, Select Committee 1859, replies to circular: 51 (Division II, Q 18). 
he could not stop it', he reiterated Billibellary's linking of the deaths to loss of country, and he noted that most deaths occurred 'about the 21st day after birth'. But he added:

I never had but one (almost evident) case of infanticide under my observation.
I was far away on the trail to Gippsland. At day break I heard the
lamentation of death ... and went direct to the lubra who had had an
infant about 3 weeks. She was in great (apparent) anguish but no babe.
I insisted on seeing it when she pointed to a little fire about 30 yards
off, and there sat the old woman who had been the nurse, with the little
innocent wrapped over and over again, and corded up for internment. I
with my knife cut the cords. The child was still warm but life had gone,
smothering, (as no marks of violence was on the body) is in my opinion
the way they despatch them. I may here remark that tho' I feel persuaded
almost all since I have been among them have been made away with, yet
such is their knowledge of my abhorrence, that when the infant is 14
or 15 days old will with a few others leave the encampment \& return
in about a fortnight invariably without their babe, their faces in deep
mourning. ${ }^{63}$

That Thomas believed that infanticide occurred cannot be doubted; but as one of the most proximate European witnesses in this colonial precinct, he is candid, in his private writings at least, in recording the lack of objective proof underpinning that belief. Against Billibellary's 'confession', and the probability that, if killings did occur, women would have hidden them from Thomas' prying eye and hand, we must balance the search by Murrun and Nerremunun for alternative explanations for the infant deaths and the barrenness that threatened the very survival of the tribes. Murrun was a woman of an age to have been directly involved in such killings if they occurred, and was therefore well positioned to know the truth of the matter. Her accusation to Thomas that it was his 'sulky' god that caused the deaths ought to stand against the unstable testimonies of Buckley and Thomas, and even that of Billibellary. The 'truth' lies in Thomas' objective record of events at Port Phillip: that these purported killings remained forever unseen by white eyes.

Finally, it is necessary to return to Billibellary's 'confession' of October 1843, linking the deaths of newborns to the loss of country. The likelihood is that some part at least of this conversation was held in the Woiwurrung language - with all the power of translation adhering to Thomas - because he gives us the phrase 'very good, weikite' in his journal entry. ${ }^{64}$ The word 'weikite', which

63 Thomas Papers, ML MS 214, Reel 21-22, frame 48-9, undated [1858], italics added. See also Fels 2010: 30-31.

64 Similarly 'weakun' in the entry of 13 February 1840, above. The word 'weikite' is consistently translated in nineteenth-century word lists as the passive 'dead' or 'is dead', and not the active, 'kill'. See William Thomas, John Green and Edward Eyre in Smyth 1876, II: 100, 119, 127, 165, 168. See also, Mathew 1899: 205, 232-233 and compare words for kill (table p. 258). Thomas also gives 'Ber-bern Weakinner - hang till dead' amongst words and phrases for use amongst prisoners in Melbourne Jail, Thomas Papers, ML MS 214, Reel 21-22, frame 37. 
runs off the edge of the page in the manuscript, has recently been transcribed as 'we kill', leaving readers in no doubt about the actions of the women. ${ }^{65}$ But linguists at the Victorian Aboriginal Corporation for Languages (VACL) have unhesitatingly identified the word as weikite, meaning 'dead', or 'are dead'. Hence, 'very good weikite and no more come up pickaniney': [it is] very good [that the children are] dead; it is right that the children are dead and no more are coming due to the loss of country. The causal link between the deaths of newborns and the loss of country folds readily into Kulin explanatory fields, requiring no active intervention by 'killing' mothers. The passive voice here, perhaps not just coincidentally, echoes Thomas' statement of 1858 that the infants 'have been made away with'.

If we suspend the infanticide explanation momentarily, an explanation for the rash of infant deaths is at hand, one requiring no intervention against viable infants by wanton killers. Thomas himself told the New South Wales Select Committee of 1849 that he had seen children born 'literally rotten' with congenital syphilis, and the reports of Henry Jones, medical dispenser to the Aborigines at Thomas' Nerre Nerre Warren station in 1842-43, also confirm the prevalence of syphilis amongst men, women, children and infants. ${ }^{66}$ Untreated syphilis is marked by miscarriage, stillbirths and deaths of newborns often within weeks of birth following the onset of 'the snuffles' and the eruption of mouth lesions which render suckling impossible leading rapidly to severe malnutrition and death. While newborns may show no symptoms, skin lesions are common, and death commonly occurs around three weeks after birth. ${ }^{67}$ The symptoms closely fit those described by Murrun as pertaining to Tolome's newborn: 'born all over sores \& only live one moon'. And this came in concert with other infectious diseases brought by the Europeans that severely compromised the viability of infants. In short, as an explanation for the severe decline in the number of infants and children amongst the Aborigines at Port Phillip during the 1840s, infanticide is extraneous.

The British humanitarian movement, which reached the peak of its influence over colonial policy in the mid 1830s, contained inherent tensions between the logics of evidence that pointed to the ills of colonialism and its bid for new domains for Christian evangelism. In the face of ethical and economic arguments against colonial expansion (fostered with some vigour by humanitarians themselves), evangelical humanitarians asserted a moral obligation to protect, civilise and Christianise the 'natives' of the empire. As the heads of the principal British mission societies argued before Buxton's committee in June 1836, the transmission of Christian knowledge and salvation was just compensation for the unstoppable occupation of native lands. It was at best a shaky logic, but was ably reinforced by the layered construction of the trope of infanticide that pitted innocent infants against their savage, ungodly mothers. Emissaries of Batman's

65 Fels 2010: 26. See also Stephens 2009: 190, in which the word was noted as 'illegible'.

66 Jones to Robinson, 1842, PROV VPRS 12 on microfilm VPRS 4467, unit 3, 5; PROV VPRS 12/ PO, unit 4, bundle 13, item 52; PROV VPRS 4410 on microfilm VPRS 4467, unit 2, items 48-51.

67 Hazen 1923: 96-97; Top and Wehrle 1976: 678-681. 
Port Phillip Association, and the first missionaries to set up at Port Phillip, happily circulated Buckley's testimony about infanticide. Other influential colonists reinforced the connection between infanticide and the decline of a people who seemed simply 'to wear out, and ... decay' before colonial 'progress' ${ }^{68} \mathrm{~A}$ decade later, the same discourse rationalised the failure of colonists in general and the officers of the Protectorate in particular, to prevent the decline in the Aboriginal population.

If the available evidence cannot prove that infanticide was not deployed by Kulin women, either as a matter of custom or as an act of tragic agency in response to the loss of their country, we ought at least accept that the evidence for its occurrence is weak and almost invariably based on hearsay. Buckley's unpublicised recantation of 1837 held no sway against the enabling testimony transmitted to London by Wedge and the Port Phillip Association in 1835. William Thomas' unstable witnessing points to the power of the discourse to self-construct across colonial domains, yet it also provides a poignant record of the struggle of Aboriginal women and men to make meaning out of the tragedy that had befallen them. Theirs too is an unstable construct, sometimes associating the loss of their children with the loss of their Country, and at other times with the malign machinations of the new world in which they found themselves. This is a discourse that contributed materially to the fashioning of the Aborigines as a dying race ripe for territorial replacement, and gave warrant to humanitarian projects of protection that carried colonisation forwards. It is a discourse with such power to shift the eye from well-established causes of Aboriginal population decline in the early colonial period to things unseen, that modern scholars would do well to note the lack of objective evidence attaching to it.

\section{References}

\section{Archival sources}

\section{Mitchell Library}

Thomas, William Papers, MS 214.

\section{Public Record Office Victoria}

VPRS 4467, 1839-1851 Aboriginal Affairs Records - Victorian Aboriginal Protector Returns (micofilm). VPRS 4467 contains:

- VPRS 11, 1841-51 Unregistered Inward Correspondence to the Chief Protector of Aborigines [VPRS 4467 Units 1, 2 \& 5]

68 Archdeacon Broughton, 3 August 1835, in House of Commons, 1836, Minutes of Evidence on Aborigines (British Settlements), p. 17, question 242, 245. 
- VPRS 12, 1840-49 Aboriginal Protectorate Returns [VPRS 4467 Units 2 \& 3]

- VPRS 4410, 1839-49 Aboriginal Protectorate Weekly, Monthly, Quarterly and Annual Reports and Journals [VPRS 4467 Unit 2]

State Library of Victoria

Barry, Redmond 1841, 'Table of Cases decided in the Supreme Court of New South Wales for the District of Port Phillip', in Redmond Barry Papers, MS 8380 , Box 597/2.

Batman, John Journal, May-June 1835, MS 13181.

Howitt, Alfred W Papers, MS 9356, Box 1053/2 (b).

Langhorne, George 1837, Reminiscences of James (sic) Buckley who lived for thirty years among the Wallawarro or Watourong tribes of Geelong communicated by him to George Langhorne. MS 13483 (digitised).

Mercer, George, Papers, MS 8519, Box 991/4 (b) 'Geelong and Dutigalla Association' 1836-7.

Orton, Joseph 1836, Journal, extracts transcribed in M Noel Orton Papers, [preaccession number] PA 94/23.

- 1836, Letterbook, extracts transcribed in M Noel Orton Papers, [pre-accession number] PA 94/23.

Thomas, William Papers, MS 14624.

Wedge, John Helder 1835, 'Journey to Examine the Country West of Indented Head', John Batman Documents, Fieldbook H1572, MS 9302, Box 23/3(a)..

- 1836, 'Mr Wedge's Narrative of an Excursion Amongst the Natives of Port Phillip', John Batman Documents 1828-35, MS 6332, MF 63: enclosure No. 2 in Arthur to Hay 28 January 1836.

\section{Official printed sources}

1836 United Kingdom, House of Commons, 'Report from the Select Committee on Aborigines (British Settlements) with Minutes of Evidence', 5 August 1836, in Britain, Parliamentary Papers, House of Commons. Reprint, Irish University Press Series of British Parliamentary Papers, 'Anthropology/Aborigines', Vol 1, Irish University Press, Shannon, 1968.

1845 New South Wales, Report from the Select Committee on the Condition of the Aborigines, Legislative Council, Votes and Proceedings, 31 October 1845. 


\section{ABORIGINAL HISTORY 2014 VOL 38}

1849 New South Wales, Report from the Select Committee on the Aborigines and Protectorate, Legislative Council, Votes and Proceedings, 4 September 1849.

1859 Victoria, Report on the Select Committee on the Aborigines, Legislative Council, Votes \& Proceedings, 3 February 1859.

\section{Secondary sources}

Bonwick, James 1883, Port Phillip Settlement, Sampson Low (\&c), London.

Bride, TF 1969 [1898], Letters from Victorian Pioneers, Heinemann, Melbourne and London.

Broome, Richard 2005, Aboriginal Victorians: A History Since 1800, Allen \& Unwin, Crows Nest, New South Wales.

Caldwell, John and Bruce Caldwell 2002, 'Family size control by infanticide in the great agrarian societies of Asia', Journal of Comparative Family Studies 36(2): 205-227.

Carey, Jane and Claire McLisky (eds) 2009, Creating White Australia, Sydney University Press, Sydney.

Clendinnen, Inga 2003, Dancing with Strangers, Text Publishing, Melbourne.

Collins, David 1798, An Account of the English Colony in New South Wales, Cadell and Davies, London.

Cowlishaw, Gillian 1978, 'Infanticide in Aboriginal Australia', Oceania, XLVIII(4): 262-282.

Federal Court of Australia 2000, 'Lorna Cubillo and Peter Gunner v Commonwealth of Australia' (Action 14 and 21 of 1996) Judgment Summary, O'Loughlin J. 11 August 2000.

Fels, Marie Hansen 2010, 'I Succeeded Once': The Aboriginal Protectorate on the Mornington Peninsula, 1839-40, Aboriginal History Inc and ANU E Press, Canberra.

Hamilton, Annette 1981, Nature and Nurture: Aboriginal Child-Rearing in NorthCentral Arnhem Land, Australian Institute of Aboriginal Studies, Canberra.

- 1989, 'Bond-slaves of Satan: Aboriginal women and the mission dilemma', in Family and Gender in the Pacific, Margaret Jolly and Martha MacIntyre (eds), Cambridge University Press, New York: 236-258. 
Hazen, HH 1923, 'Practical observations on syphilis', The American Journal of Syphilis VII: 96-97.

Howitt, Alfred W 1996 [1904], The Native Tribes of South-East Australia, Aboriginal Studies Press, Canberra.

Howitt, Alfred W and Lorimer Fison 1880, Kamilaroi and Kurnai, George Robertson, Melbourne.

Howson, Peter 1999, 'Rescued from a rabbit burrow: understanding the "Stolen Generation"', Quadrant, June 1999: 11-14.

Kenny, Robert 2008, 'Tricks or treats? A case for Kulin knowing in Batman's treaty', History Australia 5(2): 38.1-38.14.

Kociumbas, Jan 2001, 'Azaria's antecedents: stereotyping infanticide in late nineteenth-century Australia', Gender \& History 13(1): 138-160.

Lester, Alan and Fae Dussart 2008, 'Trajectories of protection: Protectorates of Aborigines in early 19th century Australia and Aotearoa New Zealand', New Zealand Geographer 64: 205-220.

Malthus, Thomas 1798, An Essay on the Principles of Population, Johnson, London.

Mathew, John 1899, Eaglehawk and Crow: A Study of the Australian Aborigines including ... a survey of Australian Languages, David Nutt, London and Melville, Mullen and Slade, Melbourne.

Morris, Grant 2014, Law Alive: The New Zealand Legal System in Context, 3rd edition, (forthcoming).

Russell, Lynette 2007, “"Dirty domestics and worse cooks”: Aboriginal women's agency and domestic frontiers, southern Australia, 1800-1850', Frontiers 28(1 \& 2): 18-46.

Sanborn, Geoffrey 1998, The Sign of the Cannibal, Duke University Press, Durham and London.

Sen, Satadru 2002, 'The Savage family: colonialism and female infanticide in nineteenth century India', Journal of Women's History 14(3): 53-81.

Smyth, Robert Brough 1876, The Aborigines of Victoria: with notes relating to the habits of the natives of other parts of Australia and Tasmania compiled from various sources for the Government of Victoria, Government Printer, Melbourne.

Stephens, Marguerita 2014, The Journal of Assistant Protector William Thomas 1839-1867 (transcription), Victorian Aboriginal Corporation for Languages, Melbourne. 


\section{ABORIGINAL HISTORY 2014 VOL 38}

- 2009, 'A word of evidence: shared tales about infanticide and "others not us" in colonial Victoria', in Creating White Australia, Jane Carey and Claire McLisky (eds), Sydney University Press, Sydney: 175-194.

Sturt, Charles 1833, Two Expeditions into the Interior of Southern Australia during the years 1828, 1829, 1830 and 1831, vol II, Smith, Elder \& Co, London.

Thomas, Tony 2014, 'How the truth went begging', Quadrant Online, 10 January 2014, http:/ /quadrant.org.au/opinion/bennelong-papers/2014/01/truthwent-begging/ (accessed 12 May 2014).

Top, FH and PF Wehrle 1976, Communicable and Infectious Diseases, Mosby, Saint Louis.

Wedge, John Helder 1836, 'On the country around Port Phillip, South Australia', Journal of the Royal Geographic Society of London 6: 419-424.

Westgarth, William 1846, A Report on the Condition, Capabilities and Prospects of the Australian Aborigines, William Clarke, Melbourne.

- 1848, Australia Felix, or a Historical and Descriptive Account of the Settlement of Port Phillip, New South Wales: Including Full Particulars of the Manners and Customs of the Aboriginal Natives, Oliver \& Boyd, Edinburgh. 
This text taken from Aboriginal History, Volume 38, edited by Shino Konishi, published 2015 by

ANU Press, The Australian National University, Canberra, Australia. 